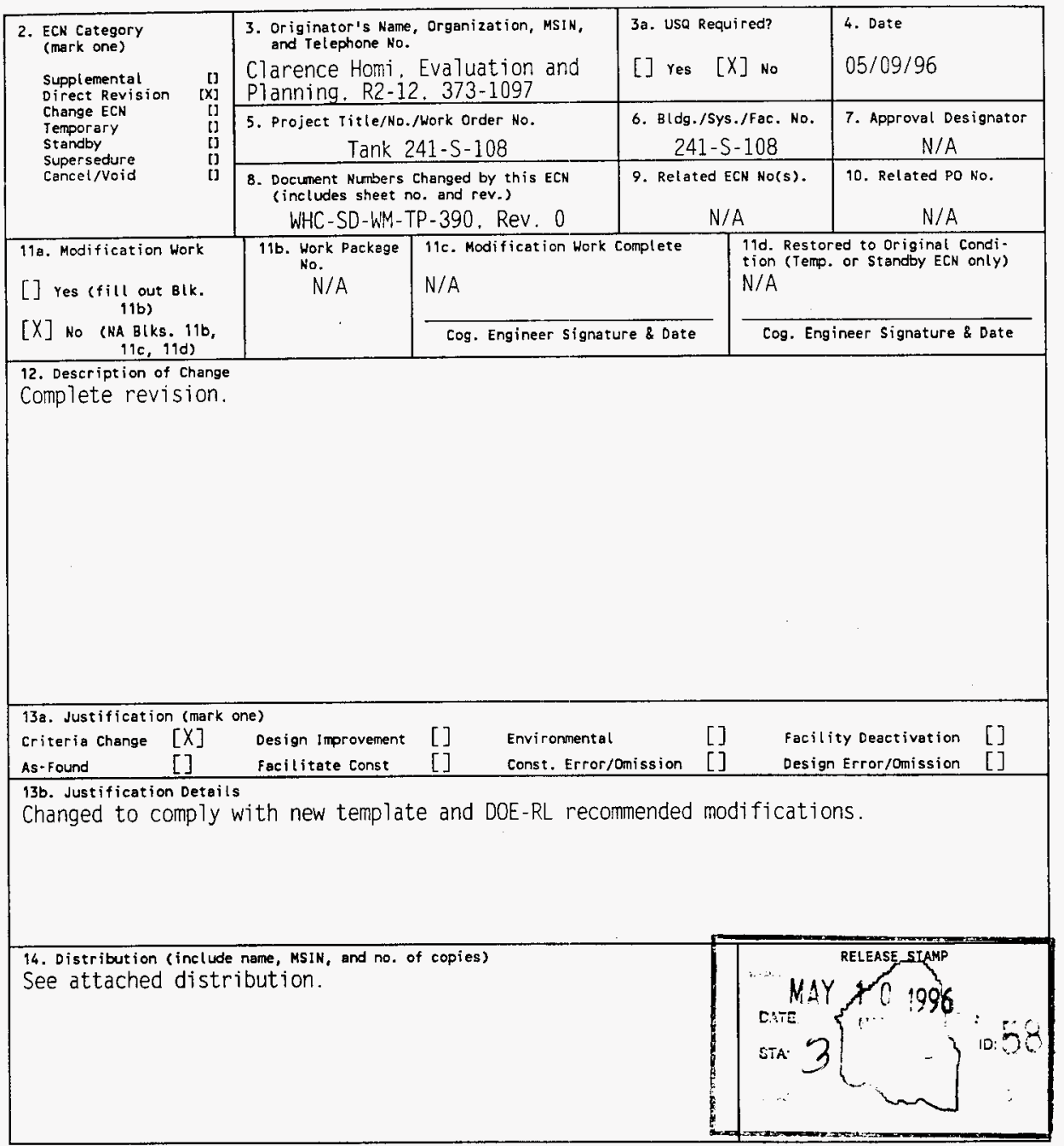




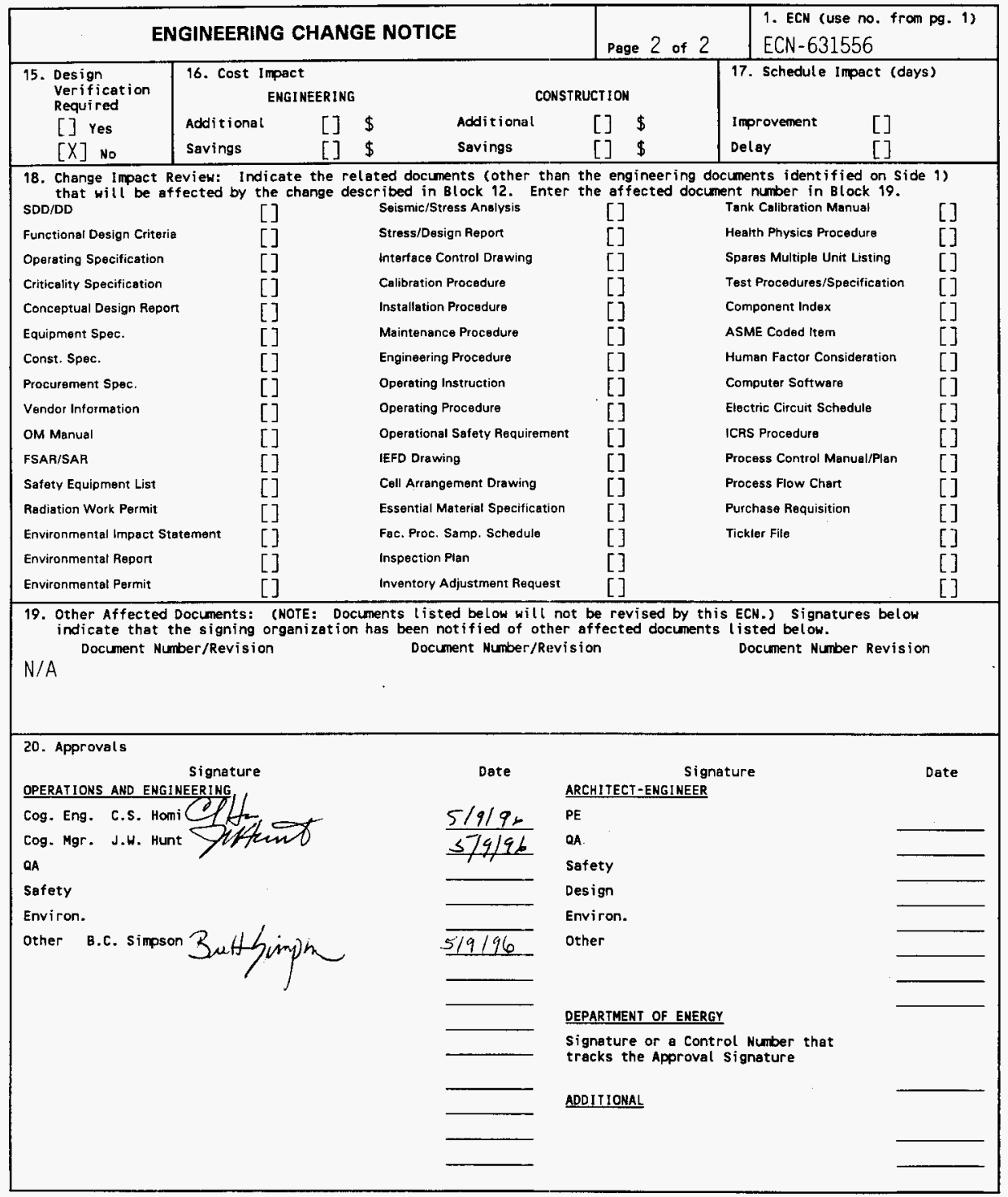




\section{Tank 241-S-108 Tank Characterization Plan}

C. S. Homi

Westinghouse Hanford Company, Richland. WA 99352

U.S. Department of Energy Contract DE-AC06-87RL10930

EDT/ECN: $\quad$ ECN-631556 UC: 2070

Org Code: $79200 \quad$ Charge Code: N4G6A

B\&R Code: EW 3120074 Total Pages: 10

Key Words: Characterization. General Safety Issues, Specific Safety Issues, Information Requirement5, Schedule

Abstract: This document is a plan that identifies the information needed to address relevant issues corcerning short-term and long-term storage and long-term management of single-shel1 tank 241-S-108.

TRADEMARK DISCLAIMER. Reference herein to any specific commercial product, process, or service by trade name, trademerk, manufacturer, or otherwise, does not necessarily constitute or imply its endorsement, recommendation, or favoring by the United States Government or any agency thereof or its contractors or subcontractors.

Printed in the United States of America. To obtain copies of this document, contact: WHC/BCS Document Control Services, P.0. Box 1970, Mailstop H6-08, Richland HA 99352, Phone (509) 372-2420. Fax (509) 376-4989.
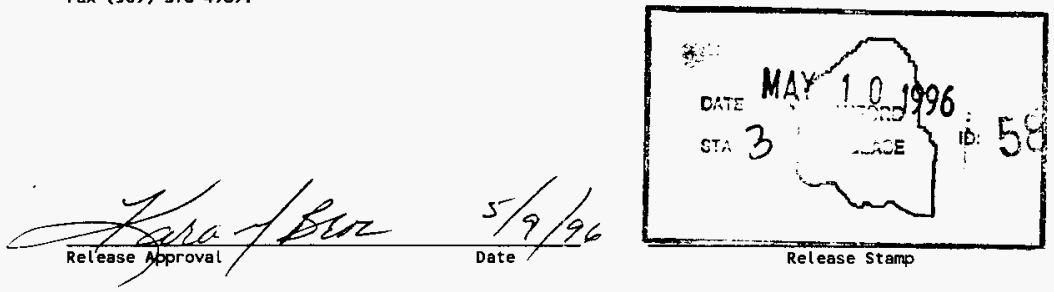

\section{Approved for Public Release}




\section{RECORD OF REVISION}

(2) Title

Tank 241-5-108 Tank Characterization Plan

CHAMGE CONTROL RECORD

(3) Revision (4) Description of Change - Replace, Add, and Delete Page

0 (7) Initially released $08 / 28 / 95$ on EDT613374

Authorized for Release

C.S. Homi S.J. Eberlein

Incorporate per ECN-631556.

C.S Homi J.W. Hunt

\begin{tabular}{|c|c|c|c|}
\hline ES 1 & Incorporate per ECN-631556 & C.S Homi & J.W. Hunt \\
\hline
\end{tabular}


WHC-SD-WM-TP-390

Revision 1

UC-2070

\section{Tank 241-S-108 Tank Characterization Plan}

B. C. Simpson

Westinghouse Hanford Company

Date Published

May 1996

Prepared for the U.S. Department of Energy Office of Environmental Restoration and

Waste Management

\section{westinghouse Hanford Company Richland, Wastinizgon}

Mangement and Operations Contractor for the

U.S. Department of Energy under Contract DE-AC06-87RL10930 
WHC-SD-WM-TP-390 REV 1

\section{TABLE OF CONTENTS}

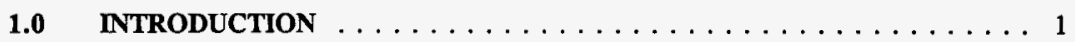

2.0 PROGRAM ELEMENTS REQUIRING INFORMATION FOR 241-S-108 . . 2

2.1 GENERAL SAFETY ISSUES $\ldots \ldots \ldots \ldots \ldots \ldots \ldots \ldots \ldots \ldots \ldots \ldots \ldots \ldots$

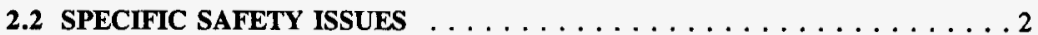

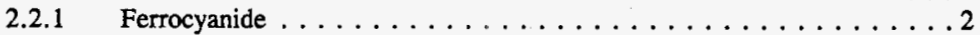

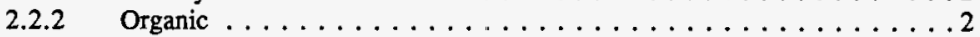

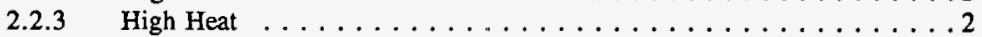

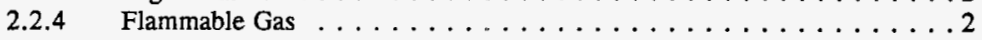

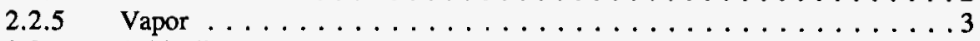

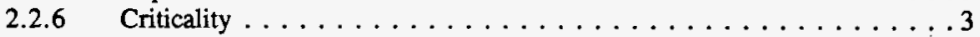

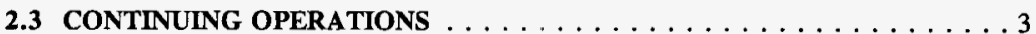

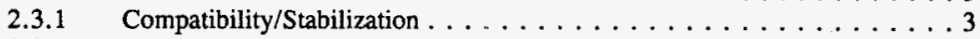

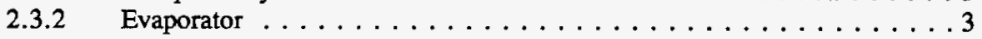

2.4 DOUBLESHELL TANK WASTE ANALYSIS PLAN $\ldots \ldots \ldots \ldots$

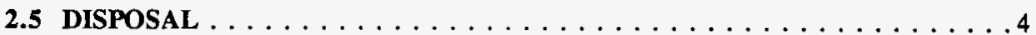

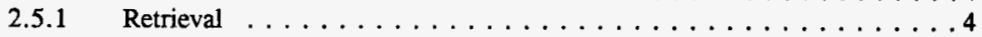

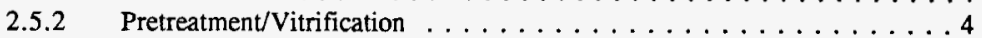

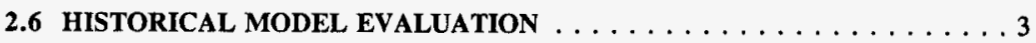

3.0 HOW INFORMATION WILL BE OBTAINED $\ldots \ldots \ldots \ldots \ldots$

4.0 PRIORITY OF INFORMATION REQUIREMENTS . . . . . . . . . . . 4

5.0 WHEN INFORMATION WILL BE AVAILABLE $\ldots \ldots \ldots \ldots$

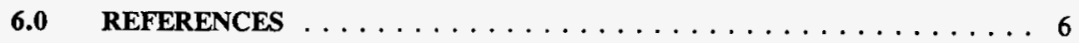

\section{LIST OF TABLES}

Table 4-1: Integrated DQO Requirements and Priorities . . . . . . . . . . . . 5 


\section{WHC-SD-WM-TP-390 REV 1}

\subsection{INTRODUCTION}

This Tank Characterization Plan (TCP) identifies the information needed to address relevant issues concerning short-term safe storage and long-term management of single-shell tank 241-S108 (S-108). It should be understood that the various needs and issues surrounding tank S-108 are evolving as new information about the tank is uncovered. As a result of this progression, this TCP addresses only the issues that, to this date, have been identified. It is expected that deviations from this plan may occur as additional issues or needs arise which impact the management of S-108. As necessary, this TCP will be revised to reflect those changes or deviations. This plan reflects the best information available as of May 1996.

Tank S-108 was constructed between 1950 and 1951 and was put into service in October 1952. Tank S-108 received Reduction Oxidation (Redox) waste via cascade, and was filled in December 1952, cascading further waste to S-109. (Brevick et al. 1994). From the third quarter of 1955 until the first quarter of 1974, there are no records indicating the tank received or transferred waste. The tank received evaporator bottoms and partially neutralized feed intermittently from the first quarter of 1974 until the first quarter of 1979 (Agnew et al. 1995). The tank is sound, and was designated out of service in 1979. Tank S-108 is passively ventilated, was partially isolated in December 1982 and is awaiting interim stabilization (Brevick et al. 1994).

Presently, the tank waste is classified as non-complexed. Tank S-108 currently contains a total waste volume of $2,286 \mathrm{~kL}(604 \mathrm{kgal})$, which is equivalent to $577 \mathrm{~cm}(227 \mathrm{in})$ of waste as measured from the baseline of the tank (Hanlon 1996).

This tank is not on any Watch List.

Near-term sampling and analysis activities are focused on either verifying or changing the Watch List tank status, and identifying any new safety issues. Should any safety issues be identified, further analyses will be directed consistent with the identified issue.

In addition to the resolution of the safety issues, it is intended that all tank waste will be subject to pretreatment and retrieval to prepare for final storage or disposal. Presently, these long-range plans have yet to be fully identified and are, therefore, not included in this document. 


\subsection{PROGRAM ELEMENTS REQUIRING INFORMATION FOR TANK 241-S-108}

This section identifies the various program elements, and identifies which of these programs require characterization data from tank $\mathrm{S}-108$.

\subsection{GENERAL SAFETY ISSUES}

The Tank Safety Screening Data Quality Objective (Dukelow et al. 1995) describes the sampling and analytical requirements that are used to screen waste tanks for unidentified safety issues. Analytical requirements for the safety screening of a tank are energetics, total alpha activity, moisture content, density, and flammable gas concentration.

\subsection{SPECIFIC SAFETY ISSUES}

\subsubsection{Ferrocyanide}

This tank is not on the Ferrocyanide Watch List, therefore, no information needs are currently identified for this program element.

\subsubsection{Organic}

This tank is not on the Organic Watch List, therefore no information needs are currently identified for this program element.

\subsubsection{High Heat}

This tank is not on the High Heat Watch List, therefore no information needs are currently identified for this program element.

\subsubsection{Flammable Gas}

This tank is not on the Flammable Gas Watch List, therefore no information needs are currently identified for this program element. 


\section{WHC-SD-WM-TP-390 REV 1}

\subsubsection{Vapor}

All 177 underground tanks must be vapor-sampled for organic solvent screening as per Recommendation 93-5 Implementation Plan (DOE-RL 1996). Some tanks may require additional vapor sampling due to other program needs. These tanks may be classified into four categories: (1) those tanks which are to be rotary mode core sampled (as a consequence of the rotary sampling system exhauster permit requirements); (2) tanks on the Organic or Ferrocyanide Watch Lists; (3) tanks in C farm; and (4) tank 241-BX-104, due to vapor exposure. Information needs must satisfy Data Quality Objectives for Tank Hazardous Vapor Safery Screening (Osborne and Buckley 1995), and for rotary mode only, Rotary Core Vapor Sampling Data Quality Objective (Price 1994) and Data Quality Objective for Regulatory Requirements for Hazardous and Radioactive Air Emissions Sampling and Analysis (Mulkey and Markillie 1995) as amended by Status of the Current Understanding of the Toxic Air Pollutants (TAPS) and Hanford Tank Farm Vapor Space Characterization; Recommended Path Forward and Justification for Continued RMCS Exhauster Operations (Laws 1996).

Tank S-108 was vapor sampled in December 1995 in support of Osborne et al. (1995).

\subsubsection{Criticality}

No information separate from that for the general safety issue of tank S-108 are currently identified for this program element. However, if the general safety screening of tank S-108 identifies a potential criticality concern, analyses for fissile materials and neutron absorbers and poisons will be performed as identified in the safety screening data quality objective (DQO).

\subsection{CONTINUING OPERATIONS}

\subsubsection{Compatibility/Stabilization}

This section does not apply to tank S-108.

\subsubsection{Evaporator}

This section does not apply to tank S-108.

\subsection{DOUBLE-SHELL TANK WASTE ANALYSIS PLAN}

This section does not apply because tank S-108 is a single-shell tank. 


\section{WHC-SD-WM-TP-390 REV 1}

\subsection{DISPOSAL}

\subsubsection{Retrieval}

Current retrieval needs (Bloom and Nguyen 1995) do not call for test samples to be taken from tank S-108.

\subsubsection{Pretreatment/Vitrification}

Tank S-108 has not been identified as a bounding tank for pretreatment/disposal process development strategy (Kupfer et al. 1995). All tanks were prioritized using the pretreatment strategy in the Tank Waste Characterization Basis (Brown et al. 1995) document and a portion of the archive material could be used for pretreatment testing, if available. The strategy does not require any specific analyses to be done on the samples.

\subsection{HISTORICAL MODEL EVALUATION}

Bounding tanks and data requirements for historical model evaluations are found in DQO Historical Model Evaluation Data Requirements (Simpson and McCain 1995). Tank S-108 has been identified as a primary bounding tank for the $\$ 1$ saltcake waste type. All single-shell tanks were prioritized using the Historical DQO in the Tank Waste Characterization Basis (Brown et al. 1995) document.

\subsection{HOW INFORMATION WILL BE OBTAINED}

The number of samples required to characterize a tank is a function of waste heterogeneity and the desired confidence to make a correct decision. As directed by the safety screening DQO, if inadequate information exists to determine an appropriate number of samples, two vertical profiles will be obtained. These vertical profiles may be obtained using core, auger (for shallow tanks), or grab samples. If analysis of these profiles reveals that additional profiles are necessary to meet data needs, more sample profiles will be requested. Prior to rotary sampling it is necessary to vapor sample the tank per the requirements of Rotary Core Sampling Data Quality Objective (Price 1994).

\subsection{PRIORITY OF INFORMATION REQUIREMENTS}

Vapor sampling was completed in December 1995. Rotary mode core sampling is scheduled in August 1997 (Stanton 1996). Refer to Table 4-1 for current DQO requirements and planned sampling and analytical requirements. 
WHC-SD-WM-TP-390 REV 1

Table 4-1: Integrated DQO Requirements and Priorities

\begin{tabular}{|c|c|c|c|}
\hline $\begin{array}{l}\text { Sampling } \\
\text { Event }\end{array}$ & Applicable Issues & Sampling Requirements & Analytical Requirements \\
\hline $\begin{array}{l}\text { Vapor } \\
\text { Sampling }\end{array}$ & $\begin{array}{l}\text {-Organic Solvent Layer } \\
\text { 93-5 Vapor Issue } \\
\text {-Rotary Mode Sampling } \\
\text { DQO } \\
\text {-Hazardous Vapor DQO }\end{array}$ & $\begin{array}{l}\text { Steel canisters, } \\
\text { Triple Sorbent Traps, } \\
\text { Sorbent Trap Systems }\end{array}$ & $\begin{array}{l}\text { Flammable Gas } \\
\text { Organic Vapors } \\
\text { Permanent Gases }\end{array}$ \\
\hline $\begin{array}{l}\text { Rotary } \\
\text { Mode } \\
\text { Core } \\
\text { Sampling }\end{array}$ & $\begin{array}{l}\text {-Safety Screening DQO } \\
\text {-Historical Model DQO }\end{array}$ & $\begin{array}{l}\text { Core samples from } 2 \text { risers } \\
\text { separated radially to the } \\
\text { maximum extent possible } \\
\text { Combustible gas } \\
\text { measurement }\end{array}$ & $\begin{array}{l}\text { Flammability, Energetics, } \\
\text { Moisture, Total alpha } \\
\text { activity, Density, Metals, } \\
\text { Anions, Radionuclides, } \\
\text { TOC }\end{array}$ \\
\hline
\end{tabular}
requirements.

\subsection{WHEN INFORMATION WILL BE AVAILABLE}

According to Stanton (1996), data are expected to be available from the rotary mode core sampling event for tank S-108 in December 1997. This time may be altered if the sampling schedule changes. Data are available from the December 1995 vapor sampling. 


\section{WHC-SD-WM-TP-390 REV 1}

\subsection{REFERENCES}

Agnew, S. F., R. A. Corbin, T. B. Duran, K. A. Jurgensen, T. P. Ortiz, and B. L. Young, 1996, Waste Status and Transaction Record Summary for the Southwest Quadrant of the Hanford 200 Area, Revision 1, WHC-SD-WM-TI-614, Westinghouse Hanford Company, Richland, Washington.

Bloom, G. R., and Q. H. Nguyen, 1995, Characterization Data Needs for Development, Design, and Operation of Retrieval Equipment Developed Through the Data Quality Objective Process, WHC-SD-WM-DQO-008, Rev. 0, Westinghouse Hanford Company, Richland, Washington.

Brevick, C. H., L. A. Gaddis, and W. W. Pickett, 1994, Supporting Document for the Historical Tank Content Estimate for S Tank Farm, WHC-SD-WM-ER-323, Rev. 0, Westinghouse Hanford Company, Richland, Washington.

Brown, T. M., S. J. Eberlein, and T. J. Kunthara, 1995, Tank Waste Characterization Basis, WHC-SD-WM-TA-164, Rev. 1, Westinghouse Hanford Company, Richland, Washington.

DOE-RL, 1996, Recommendation 93-5 Implementation Plan, DOE/RL-94-0001, Rev. 1 U.S. Department of Energy, Richland, Washington.

Dukelow, G. T., J. W. Hunt, H. Babad, and J. E. Meacham, 1995, Tank Safety Screening Data Quality Objective, WHC-SD-WM-SP-004, Rev 2, Westinghouse Hanford Company, Richland, Washington.

Hanlon, B. M., 1996, Waste Tank Summary for Month Ending January 31, 1996, WHC-EP0182-94, Westinghouse Hanford Company, Richland, Washington.

Kupfer, M. J., W. W. Schultz, and J. T. Slankas, 1995, Strategy for Sampling Hanford Site Tank Wastes for Development of Disposal Technology, WHC-SD-WM-TA-154, Rev. 1, Westinghouse Hanford Company, Richland, Washington.

Laws, G. L., 1996, Status of the Current Understanding of the Toxic Air Pollutants (TAPS) and Hanford Tank Farm Vapor Space Characterization; Recommended Path Forward and Justification for Continued RMCS Exhauster Operations, (telephone conference memorandum 01830-96-022, to Distribution, March 8), Westinghouse Hanford Company, Richland, Washington.

Mulkey, C.H., and K. D. Markillie, 1995, Data Quality Objective for Regulatory Requirements for Hazardous and Radioactive Air Emissions Sampling and Analysis, WHC-SD-WM-DQO021, Rev. 0, Westinghouse Hanford Company, Richland, Washington.

Osborne, J. W., and L. L. Buckley, 1995, Data Quality Objectives for Tank Hazardous Vapor Safety Screening, WHC-SD-WM-DQO-002, Rev. 2, Westinghouse Hanford Company, Richland, Washington. 


\section{WHC-SD-WM-TP-390 REV 1}

Osborne, J. W., J. L. Huckaby, E. R. Hewitt, C. M. Anderson, D. D. Mahlum, B. A. Pulsipher, and J. Y. Young, 1995, Data Quality Objectives for Generic In-Tank Health and Safety Vapor Issue Resolution, WHC-SD-WM-DQO-002, Rev. 1, Westinghouse Hanford Company, Richland, Washington.

Price, D. N., 1994, Rotary Core Vapor Sampling Data Quality Objective, WHC-SD-WM-SP-003, Rev. 0, Westinghouse Hanford Company, Richland, Washington.

Simpson, B. C., and D. J. McCain, 1995, Historical Model Evaluation Data Requirements, WHC-SD-WM-DQO-018, Rev. 0-A, Westinghouse Hanford Company, Richland, Washington.

Stanton, G. A., 1996, Baseline Sampling Schedule, Change 96-02, (internal memo 75610-96-06 to Distribution, April 17), Westinghouse Hanford Company, Richland, Washington. 


\section{DISTRIBUTION SHEET}

\begin{tabular}{|c|c|c|c|c|c|}
\hline \multirow{2}{*}{$\begin{array}{l}\text { To } \\
\text { Distribution }\end{array}$} & \multirow{2}{*}{\multicolumn{3}{|c|}{$\begin{array}{l}\text { From } \\
\text { Evaluation and Planning }\end{array}$}} & \multicolumn{2}{|l|}{ Page 1 of 1} \\
\hline & & & & \multicolumn{2}{|c|}{ Date $\quad 05 / 09 / 96$} \\
\hline \multicolumn{4}{|l|}{ Project Title/Work Order } & \multicolumn{2}{|c|}{ EDT No. N/A } \\
\hline \multicolumn{4}{|c|}{$\begin{array}{l}\text { WHC-SD-WM-TP-390. Rev. 1. "Tank 241-S-108 Tank Characterization } \\
\text { Plan" }\end{array}$} & \multicolumn{2}{|c|}{ ECN No. ECN-631556 } \\
\hline Name & MSIN & $\begin{array}{c}\text { Text } \\
\text { With } \\
\text { All } \\
\text { Attach. }\end{array}$ & Text 0nly & $\begin{array}{c}\text { Attach. / } \\
\text { Appendix } \\
\text { Only }\end{array}$ & $\begin{array}{l}\text { EDT/ECN } \\
\text { Only }\end{array}$ \\
\hline
\end{tabular}

\section{ONSITE}

U. S. Department of Enerqy -

Richland Field office

W. Liou

N. W. Willis

$\begin{array}{ll}57-54 & x \\ 57-54 & x\end{array}$

West inqhouse Hanford Company

G. D. Forehand

C. S. Homi

B. C. Simpson

Central files

T.C.R.C.

$\begin{array}{ll}\text { S7 }-21 & X \\ \text { R2 }-12 & X \\ \text { R2 }-12 & X \\ \text { A3 }-88 & X \\ \text { R2 }-12 & X\end{array}$

\section{OFFSITE}

U. S. Department of Enerqy - Headquarters

Office of Environmental Restoration and Waste Management EM-563

12800 Middlebrook Road

Germantown. MD 20874

J. A. Poppiti

x 